\title{
Implementasi Metode Hybrid AHP dan TOPSIS pada Sistem Pendukung Keputusan Pemilihan Lokasi Tempat Pembuangan Sampah Sementara
}

\author{
Bayhaqqi*, Saiful Bukhori**, Gayatri Dwi Santika*** \\ * Fakultas Ilmu Komputer, Universitas Jember \\ ** Fakultas Ilmu Komputer, Universitas Jember \\ ***Fakultas Ilmu Komputer, Universitas Jember \\ *bayhaqqi139@gmail.com, **saiful.ilkom@unej.ac.id, ***gayatri@unej.ac.id
}

\begin{abstract}
Temporary Waste Disposal Site (TPSS) is a place to collect waste from various community activities which will later be transported to the final disposal site by garbage trucks. There are many considerations in choosing a TPSS location, so the selection of a TPSS location is very important in supporting the collection of waste that will be transported to final disposal. The Jember Regency Environmental Service is an agency in charge of waste management, including the selection of TPSS locations. Choosing the location of TPSS so far is still manual, where manual selection cannot be separated from human error, so that choosing the location of TPSS is not accurate can cause new problems in the community. In addition, there is no standardized assessment system in the TPSS selection process, so a decision support system is needed that can be used to assist the process of selecting the best TPSS location recommendations. In making this research system, we implemented the hybrid method of AHP and TOPSIS. Where the AHP method is used to determine the weight of the criteria while the TOPSIS method is used for the selection process for TPSS candidates.
\end{abstract}

Keyword: Temporary waste disposal site, Decision support system, AHP and TOPSIS

\section{Introduction}

Tempat Pembuangan Sampah Sementara (TPSS) merupakan tempat penampungan sampah yang berasal dari berbagai aktivitas masyarakat yang nantinya akan diangkut ke Tempat Pembuangan Akhir (TPA) dengan truk sampah. Berdasarkan wawancara awal penelitian, lokasi TPSS baik di kota maupun di desa berada di sekitar perumahan warga yang cakupannya dapat menampung kurang lebih 400 rumah dengan kriteria tertentu untuk satu TPSS (UU no. 18 tahun 2008), sehingga pemilihan lokasi TPSS menjadi sangat penting dalam menunjang pengumpulan sampah yang akan diangkut ke TPA.

Wawancara penelitian awal kepada kepala bidang Kebersihan di Dinas Lingkungan Hidup (DLH) Kabupaten Jember menyatakan saat ini TPA di kabupaten Jember ditetapkan lima TPA sampah yaitu di Pakusari, Ambulu, Kencong, Tanggul dan di Rambipuji untuk wilayah Balung dan Rambipuji, sehingga kuantitas (jumlah) TPA di Kabupaten Jember bisa dikatakan cukup untuk menjangkau wilayah pelayanan jaringan persampahan. Akan tetapi itu berbanding terbalik dengan jumlah lokasi TPSS yang tersebar di desa maupun di kota, untuk TPSS dalam kota Jember yang aktif hanya 24 TPSS. Beliau menambahkan TPA tidak maksimal menyelesaikan penanganan sampah jika jumlah TPSS yang ada belum cukup untuk menampung sampah di masyarakat. Memilih lokasi TPSS baru di DLH selama ini masih menggunakan manual, dimana pemilihan tersebut tidak lepas dari kesalahan manusia, sehingga kurang tepatnya memilih lokasi TPSS bisa menimbulkan permasalahan yang baru dimasyarakat seperti bau tidak sedap, pertumbuhan penyakit, pencemaran udara, dan dampak sosial terhadap warga sekitar lokasi TPSS.

Program kerja DLH dalam menentukan lokasi TPSS membutuhkan sebuah sarana yang dapat membantu DLH dalam menentukan lokasi TPSS yang tepat. Dalam menentukan lokasi TPSS berdasarkan standart kriteria yang telah ditentukan yaitu luas minimal $400 \mathrm{~m} 2$, akses jalan untuk truk angkut sampah, cakupan jumlah rumah yang dapat ditampung, dll. yang mengacu pada Permen PU (UU no. 18 tahun 2008) tentang Tempat Pengolahan Sampah yang disesuaikan dengan kriteria yang biasa dipakai di dinas terkait. DLH dalam proses pemilihan lokasi TPSS biasanya melibatkan banyak juri/pengambil keputusan. Salah satu kendala yang dihadapi selama ini adalah sulitnya menyatukan persepsi pengambil keputusan dalam melakukan penilaian terhadap kandidat/alternatif (objek yang akan dijadikan lokasi TPSS). Kondisi ini terjadi karena ketiadaan sistem yang baku dalam melakukan proses penilaian. 
Sistem pendukung keputusan kelompok (group decision making) merupakan salah satu solusi yang bisa mengatasi persoalan pemilihan TPSS yang ada di DLH dengan model MCDM (Multi Criteria Decision Making), dimana MCDM merupakan cabang dari model riset operasi yang berhubungan dengan pengambilan keputusan menjadi pilihan yang tepat untuk diterapkan dalam melakukan proses seleksi alternatif, karena model ini sangat baik dalam melakukan proses normalisasi bobot dan proses seleksi. Model MCDM yang diusulkan yaitu metode hybrid AHP (Analytical Hierarchy Process) dan TOPSIS (Technique for Order Performance by Similarity to Ideal Solution) [11].

Dalam menghasilkan ranking alternatif, metode hybrid AHP dan TOPSIS melalui dua proses yaitu pembobotan dan seleksi. Metode AHP digunakan untuk proses pembobotan, dimana penggunaan metode ini bertujuan untuk mengurangi tingkat subjektifitas pengambil keputusan. Sedangkan metode TOPSIS digunakan untuk melakukan proses seleksi, karena konsepnya sederhana, mudah dipahami, komputasinya efisien dan cepat, [11]. Penelitian lain dilakukan oleh Chamid dkk (2017), yang menyimpulkan dari hasil kombinasikan metode AHP dan TOPSIS dapat saling melengkapi setiap kelebihan dan lemahan metode tersebut, sehingga didapatkan hasil yang lebih efektif [3]. Penelitian lain juga dilakukan oleh Sari dkk (2018), yang menganalisis perbandingan untuk menguji hasil gabungan metode AHP dan TOPSIS, didapat akurasi berdasarkan jarak Hamming sebesar 96,2\% dan jarak Euclidean 0,8096 untuk 95 sampel data mahasiswa antara tahun 2014-2016 dengan 5 kriteria, sehingga menyimpulkan bahwa gabungan metode AHP dan TOPSIS lebih baik dari pada Sistem Penunjang Keputusan (SPK) dengan metode AHP dan TOPSIS itu sendiri [12].

Penelitian ini bertujuan membangun sistem pendukung keputusan berbasis komputer dengan mengimplementasikan metode hybrid AHP dan TOPSIS untuk pemilihan lokasi TPSS di DLH Kabupaten Jember.

\section{Research Method}

Jenis penelitian yang digunakan merupakan jenis penelitian kualitatif dan kuantitatif. Penelitian kualitatif adalah penelitian yang bermaksud untuk memahami fenomena tentang apa yang dialami oleh subjek penelitian misalnya perilaku, persepsi, motivasi, tindakan, dan lain-lain, secara holistik dan dengan deskripsi kata-kata dan bahasa, pada suatu konteks khusus yang alamiah dan dengan memanfaatkan berbagai metode alamiah yang tidak menggunakan model-model matematik, statistik atau komputer. Penelitian kuantitatif pada dasarnya 24 merupakan suatu pengamatan yang melibatkan suatu ciri tertentu, berupa perhitungan, angka atau kuantitas. Penelitian kuantitatif ini didasarkan pada perhitungan persentase, ratarata, chi kuadrat, dan juga perhitungan statistik lainnya [6].

Penelitian kualitatif digunakan dalam proses analisa studi literatur yang berhubungan metode AHP dan TOPSIS dan wawancara tentang pemilihan lokasi TPSS baru di kabupaten Jember. Sedangkan penelitian kuantitatif digunakan pada proses pengolahan data dalam bentuk angka yang bertujuan untuk menentukan rangking terbaik dalam pemilihan lokasi TPSS. Pengelolahan data dilakukan dengan menggunakan metode hybrid AHP dan TOPSIS.

Tempat penelitian dilaksanakan di Dinas Lingkungan Hidup (DLH) Kabupaten Jember. Penelitian dilakukan selama 6 bulan yaitu dari bulan Januari sampai Juni 2021. Tahapan pada penelitian ini terdiri dari 3 tahapan, yaitu pengumpulan data (studi literatur dan wawancara), pengembangan sistem, dan penyusunan laporan.

Pengumpulan data merupakan langkah yang digunakan untuk memperoleh informasi yang dibutuhkan dalam rangka mencapai tujuan penelitian. Pengumpulan data diawali dengan mengumpulkan informasi yang dibutuhkan dengan penelitian. Pada penelitian ini, informasi didapatkan dengan melakukan studi literatur dan wawancara untuk mengidentifikasi permasalahan-permasalahan yang terkait dengan penelitian.

Dalam membangun sebuah sistem dibutuhkan sebuah model untuk proses pengembangan. Pada penelitian ini model yang digunakan yaitu model waterfall. Model waterfall dibagi menjadi beberapa tahap yaitu; analisis kebutuhan, desain sistem, implementasi, pengujian, dan pemeliharaan. Setiap tahapan pada waterfall tidak dapat dikerjakan sebelum tahap sebelumnya selesai.

\subsection{Sampah, TPA, dan TPS}

Sampah adalah suatu bahan yang terbuang atau dibuang dari sumber hasil aktifitas manusia maupun alam yang belum memiliki nilai ekonomis. Sampah berasal dari rumah tangga, pertanian, perkantoran, perusahaan, rumah sakit, pasar, dan lain-lain. Permasalahan sampah menjadi keluhan seluruh masyarakat desa maupun kota, oleh karena itu perlu ditangani agar tidak menimbulkan masalah yang berkelanjutan [14].

Menurut Maulidah, Tempat Pembuangan Akhir (TPA) merupakan tempat dimana sampah mencapai tahap terakhir dalam pengelolaannya sejak mulai timbul di sumber, pengumpulan, pemindahan/pengangkutan, pengolahan dan pembuangan. TPA merupakan tempat dimana sampah diisolasi secara aman agar tidak menimbulkan gangguan terhadap lingkungan sekitarnya. TPA adalah sarana fisik untuk berlangsungnya kegiatan pembuangan akhir sampah. TPA merupakan mata rantai terakhir dari pengolahan sampah perkotaan 
sebagai sarana lahan untuk menimbun atau mengolah sampah. Teknis oprasional atau proses pembuangan sampah, (jurnal yang direfenrece Fachrial dkk, 2017) [5].

Tempat Penampungan Sementara (TPS) adalah tempat sebelum sampah diangkut ke tempat pendauran ulang, pengolahan, dan/atau tempat pengolahan sampah terpadu. Tempat pengolahan sampah terpadu adalah tempat dilaksanakannya kegiatan pengumpulan, pemilahan, penggunaan ulang, pendauran ulang, pengolahan, dan pemrosesan akhir sampah. Tempat pemrosesan akhir adalah tempat untuk memroses dan mengembalikan sampah ke media lingkungan secara aman bagi manusia dan lingkungan. (UU no. 18 tahun 2008 Tentang Pengelolaan Sampah, bab 1: pasal 1, ayat 6-8) [8].

\subsection{Pengambil Keputusan}

Sistem Pendukung Keputusan merupakan suatu sistem interaktif yang membantu pengambil

keputusan melalui penggunaan data dan model-model keputusan untuk memecahkan masalah-masalah yang sifatnya semi terstruktur dan tidak terstruktur. Dasar-dasar keputusan adalah sebagai berikut:

1. Intuisi, yaitu keputusan diambil berdasarkan perasaan dan pemikiran si pengambil keputusan.

2. Pengalaman, yaitu keputusan diambil berdasarkan kejadian-kejadian yang pernah dialami sebelumnya oleh si pengambil keputusan.

3. Fakta, yaitu keputusan diambil berdasarkan data dan informasi yang telah dikumpulkan.

4. Wewenang, yaitu keputusan diambil oleh pihak yang memiliki kekuasaan dan wewenang yang lebih tinggi.

5. Rasional, yaitu keputusan yang diambil harus logis atau dapat diterima akal sehat.

Konsep Sistem Pendukung Keputusan (SPK) pertama kali diperkenalkan pada awal tahun 1970-an oleh Michael S.Scott Morton dengan istilah Decisión System, (Daihani, 2001:54) dalam (jurnal yg direfenrece Sugiyani, 2016) [14].

\subsection{Metode Analytic Hierarchy Process (AHP)}

Analytic Hierarchy Process (AHP) dikembangkan oleh Prof. Thomas L. Saaty. Sebelum datang ke Universitas Pittsburgh, Thomas L. Saaty adalah seorang profesor di Wharton School, University of Pennsylvania selama 10 tahun dan sebelum itu selama tujuh tahun di Arms Control dan Badan Perlucutan di Departemen Luar Negeri AS.

Dalam metode AHP terdapat 4 prinsip penting yang harus dipahami yaitu dekomposisi, perbandingan berpasangan, sistesis prioritas dan konsistensi logis.

1. Dekomposisi

Permasalahan multikriteria dalam AHP disederhanakan dalam bentuk hirarki yang terdiri dari 3 komponen utama, yaitu tujuan, kriteria dan alternatif pilihan. Proses penyederhanaan dari permasalahan yang kompleks menjadi bentuk hirarki ini dinamakan dekomposisi. Hirarki yang dimaksudkan dapat digambarkan sebagai berikut:

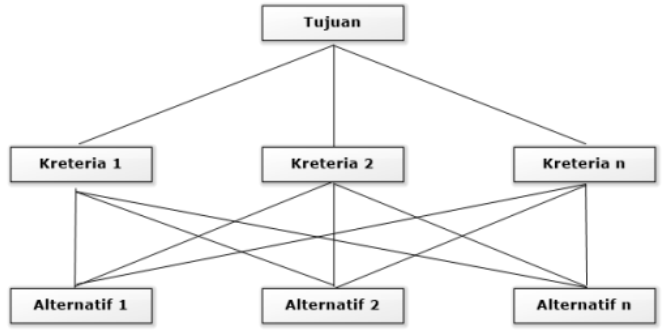

Gambar 1 Hirarki dalam AHP

2. Perbandingan berpasangan

Inti dari AHP adalah melakukan perbandingan berpasangan menggunakan tabel skala perbandingan Saaty. Panduan untuk melakukan perbandingan berpasangan dapat mengunakan tabel berikut ini:

Table 1 Skala Fundamental untuk perbandingan berpasangan

\begin{tabular}{|c|l|l|}
\hline $\begin{array}{c}\text { Tingkat } \\
\text { Kepentingan }\end{array}$ & \multicolumn{1}{|c|}{ Definisi } & \multicolumn{1}{|c|}{ Penjelasan } \\
\hline 1 & $\begin{array}{l}\text { Kedua elemen yang sama } \\
\text { pentingnya (Equal importance) }\end{array}$ & $\begin{array}{l}\text { Dua elemen dengan pengaruh } \\
\text { yang sama besar dalam } \\
\text { pengambilan keputusan }\end{array}$ \\
\hline 3 & $\begin{array}{l}\text { Elemen yang satu sedikit lebih } \\
\text { penting dari pada elemen yang } \\
\text { lainnya (Weak importance ofone } \\
\text { over another) }\end{array}$ & $\begin{array}{l}\text { Pengalaman dan penilaian } \\
\text { menyatakan bahwa satu elemen } \\
\text { sedikit lebih berperan } \\
\text { dibandingkan elemen yang } \\
\text { lainnya }\end{array}$ \\
\hline
\end{tabular}




\begin{tabular}{|c|l|l|}
\hline 5 & $\begin{array}{l}\text { Elemen yang satu lebih penting } \\
\text { daripada yang lainnya (Essential } \\
\text { or strong importance) }\end{array}$ & $\begin{array}{l}\text { Pengalaman dan penilaian } \\
\text { menyatakan bahwa satu elemen } \\
\text { sangat berperan dibandingkan } \\
\text { elemen yang lainnya }\end{array}$ \\
\hline 7 & $\begin{array}{l}\text { Satu elemen jelas mutlak lebih } \\
\text { penting daripada elemen lainnya } \\
\text { (Demonstrated importance) }\end{array}$ & $\begin{array}{l}\text { Satu elemen sangat berperan } \\
\text { dan dominan terlihat dalam } \\
\text { praktek }\end{array}$ \\
\hline 9 & $\begin{array}{l}\text { Satu elemen mutlak penting } \\
\text { daripada elemen lainnya } \\
\text { (Extreme importance) }\end{array}$ & $\begin{array}{l}\text { Bukti yang mendukung satu } \\
\text { elemen berada pada urutan } \\
\text { tertinggi. }\end{array}$ \\
\hline $2,4,6,8$ & $\begin{array}{l}\text { Nilai-nilai antara dua nilai pertimbangan-pertimbangan yang } \\
\text { berdekatan, Nilai ini diberikan bila ada dua kompromi di antara 2 } \\
\text { pilihan }\end{array}$ \\
\hline Berbalikan & $\begin{array}{l}\text { Jika untuk aktivitas i mendapat satu angka dibanding dengan } \\
\text { aktivitas j, maka j mempunyai nilai kebalikannya dibanding dengan } \\
\text { i. }\end{array}$ \\
\hline Rasio & Rasio yang di dapat langsung dari pengukuran \\
\hline
\end{tabular}

3. Sintesis prioritas (Synthesis of Priority)

Setiap kriteria yang telah ditentukan akan memiliki kontribusi terhadap pencapaian tujuan penyelesaian masalah. Dalam metode AHP setiap kriteria ditentukan besaran kontribusinya.

4. Konsistensi logis (Logical Consitency)

Dalam AHP, konsistensi logis merupakan hal yang penting.

Table 2 Daftar random indeks konsistensi

\begin{tabular}{|c|c|}
\hline Ukuran Matriks (n) & Nilai IR (Indeks Random) \\
\hline 1,2 & 0,00 \\
\hline 3 & 0,58 \\
\hline 4 & 0,90 \\
\hline 5 & 1,12 \\
\hline 6 & 1,24 \\
\hline 7 & 1,32 \\
\hline 8 & 1,41 \\
\hline 9 & 1,45 \\
\hline 10 & 1,49 \\
\hline 11 & 1,51 \\
\hline 12 & 1,48 \\
\hline 13 & 1,56 \\
\hline 14 & 1,57 \\
\hline 15 & 1,59 \\
\hline
\end{tabular}

Pada proses pengambilan keputusan, sangat penting untuk mengetahui seberapa baik konsistensi yang ada. Metode AHP mempertimbangkan suatu nilai konsistensi yang logis dalam penilaian yang digunakan untuk menentukan suatu prioritas.

Nilai konsistensi dihitung berdasarkan persamaan berikut ini:

$C I=\frac{\lambda_{m a k s}-n}{n-1}$

Keterangan:

$\mathrm{n} \quad=$ banyak kriteria

CI = Indek Konsistensi (Consistency Index)

$C R=\frac{C I}{I R}$

Keterangan:

$\mathrm{CR} \quad=$ Rasio Konsistensi

IR = Indek Rasio (nilaiindek rasio tergantung pada ukuran matriks)

Rasio konsistensi yang dihasilkan harus kurang dari 10\%, jika nilai konsistensi melebihi 10\% maka data yang diberikan oleh pengambil keputusan harus diperbaiki lagi.

Langkah-langkah yang dilakukan pada metode AHP adalah sebagai berikut: 


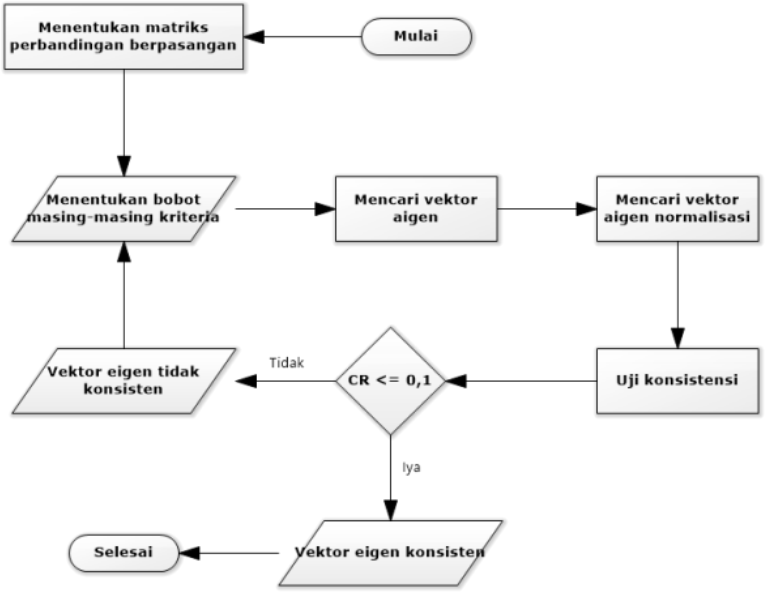

Gambar 2 Bagan alir proses metode AHP

\subsection{Metode Technique for Order Preference by Similarity to Ideal Solution (TOPSIS)}

Technique for Order Preference by Similarity to Ideal Solution (TOPSIS) adalah salah satu metode pengambilan keputusan yang dikembangkan oleh Yonn dan Hwang pada tahun 1981. Metode TOPSIS banyak digunakan untuk menyelesaikan masalah pada pengambilan keputusan secara praktis untuk menyelesaikan masalah pengambilan keputusan multikriteria.

Dalam metode TOPSIS dikenal 2 macam solusi yaitu Solusi ideal positif (PIS) dan Solusi ideal negatif (NIS) dengan rumus berikut:

$$
\begin{aligned}
& r_{i j}(x)=\frac{\left(x_{i j}-\bar{x}_{j}\right)}{\left(x_{j}{ }^{*}-\bar{x}_{j}\right)} \\
& r_{i j}(x)=\frac{\left(\bar{x}_{j}-x_{i j}\right)}{\left(\bar{x}_{j}-x_{j}{ }^{*}\right)}
\end{aligned}
$$

TOPSIS mempertimbangkan kedua solusi ini sehingga ide dasar dari metode TOPSIS adalah mencari alternatif terbaik yakni alternatif yang mempunyai jarak terkecil dari solusi ideal positif dan jarak terbesar dari solusi ideal negatif dari sudut pandang geometris dengan menggunakan jarak Euclidean untuk menentukan kedekatan relatif suatu alternatif terhadap solusi optimal. Berdasarkan perbandingan terhadap jarak relatifnya maka susunan prioritas alternatif bisa dicapai.

Langkah-langkah penyelesaian TOPSIS adalah sebagai berikut:

1. Menganalisa penyelesaian masalah untuk menentukan kriteria penyelesaian masalah.

2. Menggambarkan $\mathrm{n}$ buah alternatif dan $m$ buah kriteria ke dalam sebuah matriks.

3. Membentuk matriks keputusan normalisasi.

$$
r_{i j}=\frac{x_{i j}}{\sqrt{\sum_{i}^{n}\left(x_{i j}\right)^{2}}} \quad \mathrm{i}=1,2, \ldots, \mathrm{n} ; \mathrm{j}=1,2, \ldots, \mathrm{m} .
$$

4. Menghitung matriks keputusan terbobot.

$$
v_{i j}(x)=w_{j} r_{i j}(x), \quad \mathrm{i}=1,2, \ldots, \mathrm{n} ; \mathrm{j}=1,2, \ldots, \mathrm{m} \text {. }
$$

5. Menentukan nilai ideal positif (PIS) dan nilai ideal negatif (NIS).

$\mathrm{PIS}=A^{+}=\left\{v_{1}{ }^{+}(x), v_{2}{ }^{+}(x), \ldots, v_{j}{ }^{+}(x), \ldots v_{m}{ }^{+}(x)\right\}$

$\left.=\left\{\max _{i} v_{i j}(x) \mid j \epsilon J_{1}\right),\left({ }_{i}^{\min } v_{i j}(x) \mid j \epsilon J_{2}\right) \mid i=1,2, \ldots, n\right\}$

$\mathrm{NIS}=A^{-}=\left\{\bar{v}_{1}(x), \bar{v}_{2}(x), \ldots, \bar{v}_{j}(x), \ldots \bar{v}_{m}(x)\right\}$

$\left.=\left\{{ }_{i}^{\min } v_{i j}(x) \mid j \epsilon J_{1}\right),\left({ }_{i}^{\max } v_{i j}(x) \mid j \epsilon J_{2}\right) \mid i=1,2, \ldots, n\right\}$

6. Menghitung separation measure yakni pengukuran jarak antara suatu alternatif terhadap nilai ideal positif dan nilai ideal negatif.

$$
\begin{aligned}
& \text { Positif: } D_{i}^{+}=\sqrt{\sum_{j=1}^{m}\left[v_{i j}(x)-v_{j}^{+}(x)\right]^{2}}, \mathrm{i}=1,2, \ldots, \mathrm{n} \ldots \ldots \ldots(11) \\
& \text { Negatif: } D_{i}^{-}=\sqrt{\sum_{j=1}^{m}\left[v_{i j}(x)-v_{j}^{-}(x)\right]^{2}}, \mathrm{i}=1,2, \ldots, \mathrm{n} \ldots \ldots . .(12)
\end{aligned}
$$

7. Menentukan nilai preferensi untuk setiap alternatif $(\mathrm{Ci})$ diberikan sebagai:

$C_{i}=\frac{\bar{D}_{i}}{\left(D_{i}{ }^{*}+\bar{D}_{i}\right)^{\prime}}, \quad \mathrm{i}=1,2, \ldots, \mathrm{n}$

\section{Result and Analysis}


Penelitian ini menghasilkan sebuah sistem pendukung keputusan untuk memilih lokasi TPSS terbaik berbasis komputer. Sistem dibangun menggunakan metode hybrid AHP dan TOPSIS, dengan kata lain mengkombinasikan antara metode AHP dan TOPSIS. Dalam menghasilkan alternatif terbaik, sistem mengakomodir keterlibatan banyak pengambil keputusan (group decision making). metode AHP digunakan untuk proses pembobotan kriteria, sedangkan metode TOPSIS digunakan untuk proses seleksi.

\subsection{Proses Pembobotan Kriteria Menggunakan Metode AHP}

Untuk menguji kinerja sistem. Penulis melakukan simulasi dengan menggunakan data terdahulu atau data yang sudah ada di DLH Kabupaten Jember. Kandidat yang dipilih diambil sebanyak 5 kandidat/alternatif (calon TPSS baru) dalam hal ini diwakilkan dengan simbol A1 s.d A5 seperti pada (Table 3), Sedangkan dengan Pengambil Keputusan (PK) sebanyak 3 orang yang disimbolkan dengan PK1 s.d PK2 seperti pada (Table 4) dengan menggunakan 7 kriteria penilaian seperti pada (Table 11).

\begin{tabular}{|c|c|c|c|c|c|c|c|}
\hline Kode & $\mathrm{A} 1$ & \multicolumn{2}{|c|}{ tif/kandia } & & & A4 & 5 \\
\hline Keterangan & Kandidat 1 & Kandida & & Kandidat 3 & & ndidat 4 & Kandidat 5 \\
\hline \multicolumn{8}{|c|}{ Table 4 Daftar pengambil keputusan } \\
\hline Kode & \multicolumn{2}{|c|}{ PK1 } & \multicolumn{3}{|c|}{ PK2 } & \multicolumn{2}{|c|}{ PK3 } \\
\hline Keterangan & \multicolumn{2}{|c|}{ Peng. Keputusan 1} & \multicolumn{3}{|c|}{ Peng. Keputusan 2} & \multicolumn{2}{|c|}{ Peng. Keputusan 3} \\
\hline
\end{tabular}

Berpedoman pada langkah-langkah metode AHP maka prosesnya sebagai berikut:

1. Mendefinisikan Masalah dan Menentukan Solusi yang Diinginkan

Mendefinisikan masalah dan memilih metode AHP untuk menyelesaikan permasalahan diatas. Pada tahap ini kita akan menentukan tujuan, kriteria dan alternatif yang ada, sebagai berikut:

Tujuan : Memilih lokasi Tempat Pembuangan Sampah Sementara (TPSS)

Kriteria $\quad$ : Ansori (PK1), Dany (PK2), dan Irham (PK3)

Alternatif : Luas lahan (C1), Tempat parkir truk (C2), Partisipasi masyarakat (C3), Cakupan rumah (C4), Jarak ke pemukiman (C5), Akses jalan (C6), dan Pemilik tanah (C7)

\section{Membuat Struktur Hirarki}

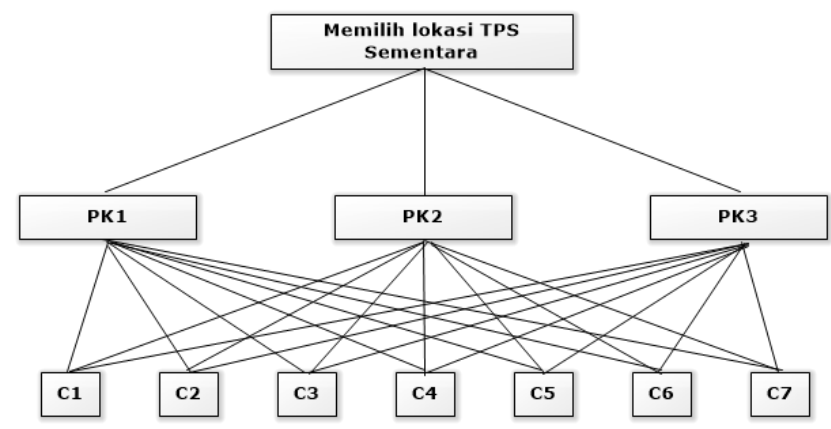

Gambar 3 Struktur hirarki pemilihan lokasi TPS Sementara

\section{Membuat Matriks Perbandingan Berpasangan}

Membuat matriks perbandingan berpasangan. Dalam kasus ini kita memiliki 3 buah kriteria yakni orang Pengambil Keputusan $(\mathrm{PK})=\{\mathrm{PK} 1, \mathrm{PK} 2$, dan PK3 $\}$ dan 7 buah alternatif yakni $\mathrm{C}=\{\mathrm{C} 1, \mathrm{C} 2$, C3, C4, C5, C6, dan C7 \}, seperti telah diuraikan pada langkah-langkah dalam AHP, kita akan melakukan 4 kali perbandingan berpasangan sebagai berikut:

- Perbandingan antar kriteria yang akan membentuk matriks 3 × 3 .

- Perbandingan masing-masing alternatif terhadap kriteria PK1 yang akan membentuk matriks $7 \times 7$.

- Perbandingan masing-masing alternatif terhadap kriteria PK2 yang akan membentuk matriks 7 x 7.

- $\quad$ Perbandingan masing-masing alternatif terhadap kriteria PK3 yang akan membentuk matriks $7 \times 7$.

Pada masing-masing perbandingan berpasangan kita akan menghitung vektor eigen normalisasi dan memeriksa konsistensi hirarki. 


\section{PERHITUNGAN UNTUK PERBANDINGAN ANTAR KRITERIA}

Nilai pada matriks perbandingan berpasangan ini didasarkan pada penilaian kepala bidang kepada pengambil keputusan. Pada studi kasus pemilihan lokasi TPSS ini didapat data sebagai berikut:

- $\quad$ PK1 antara sama penting dan sedikit lebih penting dari PK2

- $\quad$ PK1 antara sama penting dan sedikit lebih penting dari PK3

- $\quad$ PK2 sama penting dengan PK3

Data diatas masih dalam bentuk data kualitatif, kita akan mengubah data kualitatif tersebut kedalam bentuk kuantitatif sesuai dengan skala fundamental untuk perbandingan berpasangan pada AHP sehingga diperoleh:

Table 5 Matrik perbandingan berpasangan untuk kriteria

\begin{tabular}{|c|c|c|c|}
\hline Kriteria & PK1 & PK2 & PK3 \\
\hline PK1 & 1 & 2 & 2 \\
\hline PK2 & 0,500 & 1 & 1 \\
\hline PK3 & 0,500 & 1,000 & 1 \\
\hline
\end{tabular}

4. Menghitung Vektor Eigen Normalisasi

Untuk menghitung nilai vektor eigen normalisasi kita akan menggunakan (Table 5) dengan cara mengalikan kolom dan baris sebagai berikut:

$a_{11}=(1 * 1)+(2 * 0,500)+(2 * 0,500)=3,000$

Nilai a11 ini diperoleh dengan mengalikan baris 1 dengan kolom 1 , sedangkan nilai a12 diperoleh dengan mengalikan baris 1 dengan kolom 2, demikian juga dengan nilai matriks yang lain diperoleh dengan cara yang sama.

$a_{12}=(1 * 2)+(2 * 1)+(2 * 1,000)=6,000$

$a_{13}=(1 * 2)+(2 * 1)+(2 * 1)=6,000 \ldots$

Selanjutnya kita menjumlahkan nilai pada baris, lalu menjumlahkan hasil penjumlahan secara keseluruhan.

Baris $_{1}=3,000+6,000+6,000=15,000$

Baris $_{2}=1,500+3,000+3,000=7,500$

Baris $_{3}=1,500+3,000+3,000=7,500$

Total $_{\text {baris }}=15,000+7,500+7,500=30,000$

Nilai eigen vektor normalisasi dihasilkan dengan membagi nilai penjumlahan masing-masing baris dengan total keseluruhan.

Eigen Vektor $_{1}=15,000 / 30,000=0,500$

Eigen Vektor $_{2}=7,500 / 30,000=0,250$

Eigen Vektor $_{1}=7,500 / 30,000=0,250$

Hasil perhitungan yang telah dilakukan diatas di buat dalam tabel berikut:

Table 6 Hasil vektor eigen normalisasi

\begin{tabular}{|c|c|c|c|c|c|}
\hline Kriteria & PK1 & PK2 & PK3 & & Vektor Eigen Normalisasi \\
\hline PK1 & 3,000 & 6,000 & 6,000 & 15,000 & 0,500 \\
\hline PK2 & 1,500 & 3,000 & 3,000 & 7,500 & 0,250 \\
\hline PK3 & 1,500 & 3,000 & 3,000 & 7,500 & 0,250 \\
\hline
\end{tabular}

\section{Memeriksa Konsistensi Hirarki}

Rasio konsistensi ini digunakan untuk mengetahui tingkat konsistensi penilaian perbandingan kriteria.

- $\quad$ Menentukan nilai eigen maksimal ( $\lambda$ maks)

Nilai eigen maksimal ( $\lambda$ maks) diperoleh dengan mengalikan hasil penjumlahan setiap baris pada matriks perbandingan berpasangan dengan vektor eigen normalisasi.

$\lambda_{\text {maks }}=(2,000 * 0,500)+(4,000 * 0,250)+(4 * 0,250)=3,00000$

- $\quad$ Menghitung indek konsistensi (CI)

Berdasarkan rumus $C I=\frac{\lambda_{\text {maks }}-n}{n-1}$ diperoleh: 
$C I=\frac{3,00000-3}{2}=0,00000$

- $\quad$ Menghitung rasio konsistensi (CR)

Berdasarkan pada daftar random indeks konsistensi diperoleh bahwa IR untuk matriks berukuran $3 \times 3$ adalah 0.58 , sehingga berdasarkan pada $C R=\frac{C I}{I R}$ diperoleh:

$C R=\frac{0,00000}{0,58}=0,00000$

Karena CR < 0.1 maka preferensi pembobotan adalah konsisten. Hasil perhitungan diatas dapat digambarkan dalam sub hirarki yang membandingkan antar kriteria sebagai berikut:

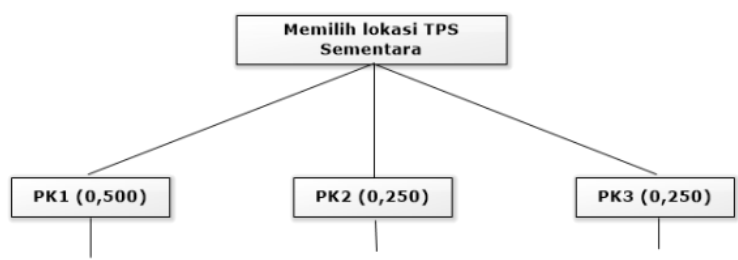

Gambar 4 Struktur sub hirarki untuk kriteria

PERHITUNGAN UNTUK PERBANDINGAN ANTAR ALTERNATIF

Ulangi langkah 3 sampai 5 untuk tingkatan selanjutnya, yaitu perbandingan masing-masing alternatif terhadap masing-masing kriteria dengan menggunakan data berikut.

Table 7 Matrik perbandingan berpasangan kriteria PK1

\begin{tabular}{|c|c|c|c|c|c|c|c|}
\hline PK1 & C1 & C2 & C3 & C4 & C5 & C6 & C7 \\
\hline C1 & 1,000 & 0,333 & 0,200 & 1,000 & 1,000 & 7,000 & 0,200 \\
\hline C2 & 3,000 & 1,000 & 0,500 & 3,000 & 3,000 & 7,000 & 0,333 \\
\hline C3 & 5,000 & 2,000 & 1,000 & 5,000 & 5,000 & 3,000 & 0,333 \\
\hline C4 & 1,000 & 0,333 & 0,200 & 1,000 & 1,000 & 5,000 & 0,200 \\
\hline C5 & 1,000 & 0,333 & 0,200 & 1,000 & 1,000 & 5,000 & 0,143 \\
\hline C6 & 0,143 & 0,143 & 0,333 & 0,200 & 0,200 & 1,000 & 0,125 \\
\hline C7 & 5,000 & 3,000 & 3,000 & 5,000 & 7,000 & 8,000 & 1,000 \\
\hline
\end{tabular}

Table 8 Matrik perbandingan berpasangan kriteria PK2

\begin{tabular}{|c|c|c|c|c|c|c|c|}
\hline PK2 & C1 & C2 & C3 & C4 & C5 & C6 & C7 \\
\hline C1 & 1,000 & 0,200 & 0,200 & 0,333 & 1,000 & 7,000 & 0,333 \\
\hline C2 & 5,000 & 1,000 & 1,000 & 3,000 & 5,000 & 7,000 & 0,500 \\
\hline C3 & 5,000 & 1,000 & 1,000 & 3,000 & 3,000 & 5,000 & 0,333 \\
\hline C4 & 3,000 & 0,333 & 0,333 & 1,000 & 1,000 & 5,000 & 0,200 \\
\hline C5 & 1,000 & 0,200 & 0,333 & 1,000 & 1,000 & 5,000 & 0,125 \\
\hline C6 & 0,143 & 0,143 & 0,200 & 0,200 & 0,200 & 1,000 & 0,167 \\
\hline C7 & 3,000 & 2,000 & 3,000 & 5,000 & 8,000 & 6,000 & 1,000 \\
\hline
\end{tabular}

Table 9 Matrik perbandingan berpasangan kriteria PK3

\begin{tabular}{|c|c|c|c|c|c|c|c|}
\hline PK3 & C1 & C2 & C3 & C4 & C5 & C6 & C7 \\
\hline C1 & 1,000 & 0,333 & 0,200 & 0,500 & 1,000 & 7,000 & 0,200 \\
\hline C2 & 3,000 & 1,000 & 2,000 & 2,000 & 5,000 & 7,000 & 0,500 \\
\hline C3 & 5,000 & 0,500 & 1,000 & 3,000 & 3,000 & 5,000 & 0,333 \\
\hline C4 & 2,000 & 0,500 & 0,333 & 1,000 & 2,000 & 5,000 & 0,200 \\
\hline C5 & 1,000 & 0,200 & 0,333 & 0,500 & 1,000 & 5,000 & 0,167 \\
\hline C6 & 0,143 & 0,143 & 0,200 & 0,200 & 0,200 & 1,000 & 0,167 \\
\hline C7 & 5,000 & 2,000 & 3,000 & 5,000 & 6,000 & 6,000 & 1,000 \\
\hline
\end{tabular}


Hasil perhitungan diatas dapat diringkas dalam bentuk gambar struktur hirarki sebagai berikut:

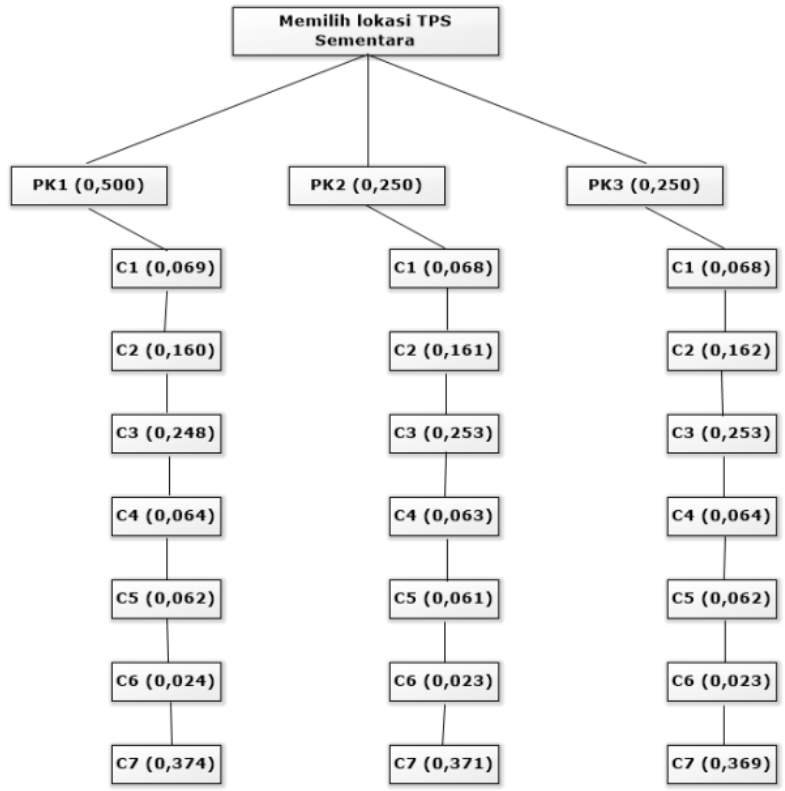

Gambar 5 Struktur hirarki beserta nilai vektor eigen normalisasi

6. Melakukan Perhitungan Akhir

Selanjutnya adalah melakukan perhitungan peringkat alternatif berdasarkan pada vector eigen normalisasi, nilai berikut diperoleh dari hasil perhitungan vector eigen yang telah diuraikan diatas

$C 1=(0,069 * 0,500)+(0,068 * 0,250)+(0,068 * 0,250)=0,067$

$C 2=(0,160 * 0,500)+(0,161 * 0,250)+(0,162 * 0,250)=0,190$

$C 3=(0,248 * 0,500)+(0,253 * 0,250)+(0,253 * 0,250)=0,220 \ldots$

Sehingga didapatkan hasil sebagai berikut, yang nantinya akan dijadikan nilai bobot pada proses seleksi menggunakan metode TOPSIS.

Table 10 Hasil proses pembobotan kriteria menggunakan metode AHP

\begin{tabular}{|c|l|c|}
\hline Kriteria & \multicolumn{1}{|c|}{ Nama Kriteria } & Bobot \\
\hline C1 & Luas lahan & 0,067 \\
\hline C2 & Tempat parkir truk & 0,190 \\
\hline C3 & Partisipasi masyarakat & 0,220 \\
\hline C4 & Cakupan rumah & 0,079 \\
\hline C5 & Jarak ke pemukiman & 0,061 \\
\hline C6 & Akses jalan & 0,023 \\
\hline C7 & Pemilik tanah & 0,360 \\
\hline
\end{tabular}

\subsection{Proses Seleksi TPSS Menggunakan Metode TOPSIS}

Berpedoman pada langkah-langkah metode TOPSIS maka prosesnya sebagai berikut:

1. Menganalisa Penyelesaian Masalah untuk Menentukan Kriteria Penyelesaian Masalah

Berdasarkan teori tentang studi kelayakan pemilihan lokasi TPSS terdapat 7 kriteria yang dapat digunakan, yang ditunjukan pada tabel berikut:

Table 11 Indikator penilaian pada tiap kriteria

\begin{tabular}{|c|l|l|c|}
\hline Kriteria & Nama Kriteria & \multicolumn{1}{|c|}{ Indikator } & Nilai \\
\hline \multirow{3}{*}{$\mathrm{C} 1$} & Luas lahan & Sangat sempit $(>=100 \mathrm{~m} 2)$ & 1 \\
\cline { 3 - 4 } & & Sempit $(>=200 \mathrm{~m} 2)$ & 2 \\
\cline { 3 - 4 } & & Sedikit Sempit $(>=300 \mathrm{~m} 2)$ & 3 \\
\cline { 3 - 4 } & Lumayan luas $(>=400 \mathrm{~m} 2)$ & 4 \\
\cline { 3 - 4 } & & Cukup luas $(>=500 \mathrm{~m} 2)$ & 5 \\
\cline { 3 - 4 } & & Luas $(>=600 \mathrm{~m} 2)$ & 6 \\
\hline
\end{tabular}




\begin{tabular}{|c|c|c|c|}
\hline & & Sangat luas $(>=700 \mathrm{~m} 2)$ & 7 \\
\hline \multirow[t]{6}{*}{$\mathrm{C} 2$} & \multirow{6}{*}{$\begin{array}{l}\text { Tempat parkir } \\
\text { truk }\end{array}$} & Tidak ada parkir truk & 1 \\
\hline & & Parkir truk sempit & 2 \\
\hline & & Parkir truk cukup & 3 \\
\hline & & Parkir truk luas & 4 \\
\hline & & Parkir truk sangat luas & 5 \\
\hline & & Bisa menampung lebih dari 1 truk & 6 \\
\hline \multirow[t]{5}{*}{ C3 } & \multirow{5}{*}{$\begin{array}{l}\text { Partisipasi } \\
\text { masyarakat }\end{array}$} & Respon tidak baik & 1 \\
\hline & & Respon kurang baik & 2 \\
\hline & & Respon cukup baik & 3 \\
\hline & & Respon Sangat baik & 4 \\
\hline & & Tidak ada respon & 5 \\
\hline \multirow[t]{6}{*}{$\mathrm{C} 4$} & \multirow[t]{6}{*}{ Cakupan rumah } & Kurang lebih 100 rumah & 1 \\
\hline & & Kurang lebih 200 rumah & 2 \\
\hline & & Kurang lebih 600 rumah & 3 \\
\hline & & Kurang lebih 300 rumah & 4 \\
\hline & & Kurang lebih 500 rumah & 5 \\
\hline & & Kurang lebih 400 rumah & 6 \\
\hline \multirow[t]{5}{*}{ C5 } & \multirow{5}{*}{$\begin{array}{l}\text { Jarak } \\
\text { kepemukiman }\end{array}$} & Berdampingan dengan pemukiman & 1 \\
\hline & & Dekat dengan pemukiman & 2 \\
\hline & & Cukup jauh dengan pemukiman & 3 \\
\hline & & Jauh dari pemukiman & 4 \\
\hline & & Tidak ada pemukiman & 5 \\
\hline \multirow[t]{5}{*}{ C6 } & \multirow[t]{5}{*}{ Akses jalan } & Sulit diakses truk sampah & 1 \\
\hline & & Sedikit sulit diakses truk sampah & 2 \\
\hline & & Cukup diakses truk sampah & 3 \\
\hline & & Bisa diakses truk sampah & 4 \\
\hline & & Sangat bisa diakses truk sampah & 5 \\
\hline \multirow[t]{6}{*}{$\mathrm{C7}$} & \multirow[t]{6}{*}{ Pemilik tanah } & Organisasi sosial atau agama & 1 \\
\hline & & Lebih dari satu status kepemilikan & 2 \\
\hline & & Swasta/perusahaan & 3 \\
\hline & & Pribadi & 4 \\
\hline & & Pemerintah & 5 \\
\hline & & Fasilitas umum & 6 \\
\hline
\end{tabular}

2. Menggambarkan $\mathbf{n}$ Buah Alternatif dan $\mathbf{m}$ Buah Kriteria ke dalam Sebuah Matriks

Merepresentasikan data awal TOPSIS dalam bentuk tabel. Nilai data Xij pada matriks ini diisikan berdasarkan data dan informasi yang didapat dari orang selaku pengambil keputusan yaitu Ansori (PK1), Dany (PK2), dan Irham (PK3) yang telah diolah sehingga didapat rata-rata penilaian sebagai berikut ini:

Table 12 Representasi data awal TOPSIS untuk pemilihan lokasi TPSS

\begin{tabular}{|l|c|c|c|c|c|c|c|}
\hline \multicolumn{1}{|c|}{ Alternatif } & C1 & C2 & C3 & C4 & C5 & C6 & C7 \\
\hline TP Arjasa & 4,333 & 5,667 & 4,667 & 2,000 & 4,667 & 2,333 & 3,000 \\
\hline TP Cendrawasih & 2,667 & 4,667 & 3,000 & 3,333 & 2,333 & 4,667 & 4,333 \\
\hline TP Imam Bonjol & 5,333 & 2,667 & 3,333 & 6,000 & 4,667 & 3,333 & 4,000 \\
\hline TP Kenanga & 1,333 & 6,000 & 4,333 & 2,333 & 3,667 & 5,000 & 2,667 \\
\hline
\end{tabular}




\begin{tabular}{|l|l|l|l|l|l|l|l|}
\hline TP Mastrip & 2,667 & 2,333 & 3,667 & 3,667 & 3,333 & 4,667 & 5,000 \\
\hline W (Bobot) & 0,067 & 0,190 & 0,220 & 0,079 & 0,061 & 0,023 & 0,360 \\
\hline
\end{tabular}

Nilai bobot (W) diisi berdasarkan tingkat kepentingan masing-masing kriteria yang didapat dari hasil proses pembobotan kriteria menggunakan metode AHP pada (Table 10).

3. Membentuk Matriks Keputusan Normalisasi

Untuk membentuk matriks normalisasi, kita menggunakan rumus $r_{i j}=\frac{x_{i j}}{\sqrt{\sum_{i}^{n}\left(x_{i j}\right)^{2}}}$, sehingga dihasilkan:

Table 13 Matriks normalisasi untuk pemilihan TPSS

\begin{tabular}{|l|c|c|c|c|c|c|c|}
\hline & r1 & r2 & r3 & r4 & r5 & r6 & r7 \\
\hline TP Arjasa & 0,545 & 0,560 & 0,542 & 0,239 & 0,544 & 0,253 & 0,344 \\
\hline TP Cendrawasih & 0,335 & 0,461 & 0,348 & 0,398 & 0,272 & 0,506 & 0,497 \\
\hline TP Imam Bonjol & 0,671 & 0,263 & 0,387 & 0,717 & 0,544 & 0,361 & 0,459 \\
\hline TP Kenanga & 0,168 & 0,593 & 0,503 & 0,279 & 0,428 & 0,542 & 0,306 \\
\hline TP Mastrip & 0,335 & 0,231 & 0,426 & 0,438 & 0,389 & 0,506 & 0,574 \\
\hline W (Bobot) & 0,067 & 0,190 & 0,220 & 0,079 & 0,061 & 0,023 & 0,360
\end{tabular}

4. Menghitung Matriks Keputusan Terbobot

Untuk menghitung matriks keputusan terbobot kita menggunakan rumus $v_{i j}(x)=w_{j} r_{i j}(x)$ yakni mengalikan matriks keputusan normalisasi dengan bobot (W), sehingga dihasilkan:

Table 14 Matriks keputusan terbobot

\begin{tabular}{|l|c|c|c|c|c|c|c|}
\hline & $\mathbf{v 1}$ & $\mathbf{v 2}$ & $\mathbf{v 3}$ & $\mathbf{v 4}$ & $\mathbf{v 5}$ & $\mathbf{v 6}$ & $\mathbf{v 7}$ \\
\hline TP Arjasa & 0,036 & 0,107 & 0,119 & 0,019 & 0,033 & 0,006 & 0,124 \\
\hline TP Cendrawasih & 0,022 & 0,088 & 0,077 & 0,031 & 0,017 & 0,012 & 0,179 \\
\hline TP Imam Bonjol & 0,045 & 0,050 & 0,085 & 0,057 & 0,033 & 0,008 & 0,165 \\
\hline TP Kenanga & 0,011 & 0,113 & 0,111 & 0,022 & 0,026 & 0,013 & 0,110 \\
\hline TP Mastrip & 0,022 & 0,044 & 0,094 & 0,035 & 0,024 & 0,012 & 0,207 \\
\hline
\end{tabular}

5. Menentukan Nilai Ideal Positif (PIS) dan Nilai Ideal Negatif (NIS)

Untuk menentukan nilai PIS dan NIS ini kita cari nilai terbesar dan terkecil tiap kolomnya.

$P I S=A^{+}=[0,0450,1130,1190,0570,0330,0130,207]$

$N I S=A^{-}=[0,0110,0440,0770,0190,0170,0060,110]$

6. Menghitung Separation Measure

Menghitung separation measure yakni pengukuran jarak antara suatu alternatif terhadap nilai ideal positif (PIS) dan nilai ideal negatif (NIS) dengan menggunakan rumus $D_{i}{ }^{+}=$ $\sqrt{\sum_{j=1}^{m}\left[v_{i j}(x)-v_{j}^{+}(x)\right]^{2}}$, dan ${D_{i}}^{-}=\sqrt{\sum_{j=1}^{m}\left[v_{i j}(x)-v_{j}^{-}(x)\right]^{2}}$, Sehingga diperoleh tabel berikut ini:

Table 15 PIS dan NIS untuk pemilihan lokasi TPSS

\begin{tabular}{|l|c|c|}
\hline & Di + & Di - \\
\hline TP Arjasa & 0,092 & 0,083 \\
\hline TP Cendrawasih & 0,068 & 0,084 \\
\hline TP Imam Bonjol & 0,083 & 0,077 \\
\hline TP Kenanga & 0,108 & 0,078 \\
\hline TP Mastrip & 0,080 & 0,100 \\
\hline
\end{tabular}

7. Menentukan Nilai Preferensi untuk Setiap Alternatif (Ci) 
Menghitung $\mathrm{Ci}$ dengan menggunakan rumus $C_{i}=\frac{\bar{D}_{i}}{\left(D_{i}{ }^{*}+\bar{D}_{i}\right)}$, sehingga diperoleh nilai akhir tabel berikut:

Table 16 Nilai preferensi untuk setiap alternatif

\begin{tabular}{|l|c|}
\hline & $\mathbf{C i}$ \\
\hline TP Arjasa & 0,474 \\
\hline TP Cendrawasih & 0,552 \\
\hline TP Imam Bonjol & 0,484 \\
\hline TP Kenanga & 0,418 \\
\hline TP Mastrip & 0,555 \\
\hline
\end{tabular}

Berdasarkan nilai Ci maka lokasi TPSS terbaik adalah TPSS yang berada di Jalan Mastrip yaitu Transfer Depo Mastrip.

Berdasarkan pengujian manual menggunakan aplikasi microsoft excel dan sistem yang dibuat didapatkan perbedaan pembulatan nilai tapi tidak mempengaruhi peringkat akhir. Berdasarkan perbandingan tersebut akurasi perhitungan sistem lebih akurat dibandingkan dengan perhitungan manual dikarenakan perhitungan manual hanya menggunakan 3 angka di belakang koma, sedangkan perhitungan sistem lebih dari 3 anggka dibelakang koma. Sehingga bisa dikatakan tingkat akurasi perhitungan sudah sesuai yaitu lebih dari 95\% dengan perbandingan perhitungan secara manual.

\section{Conclusion}

Berdasarkan penelitian yang telah dilakukan dapat diambil kesimpulan sebagai berikut:

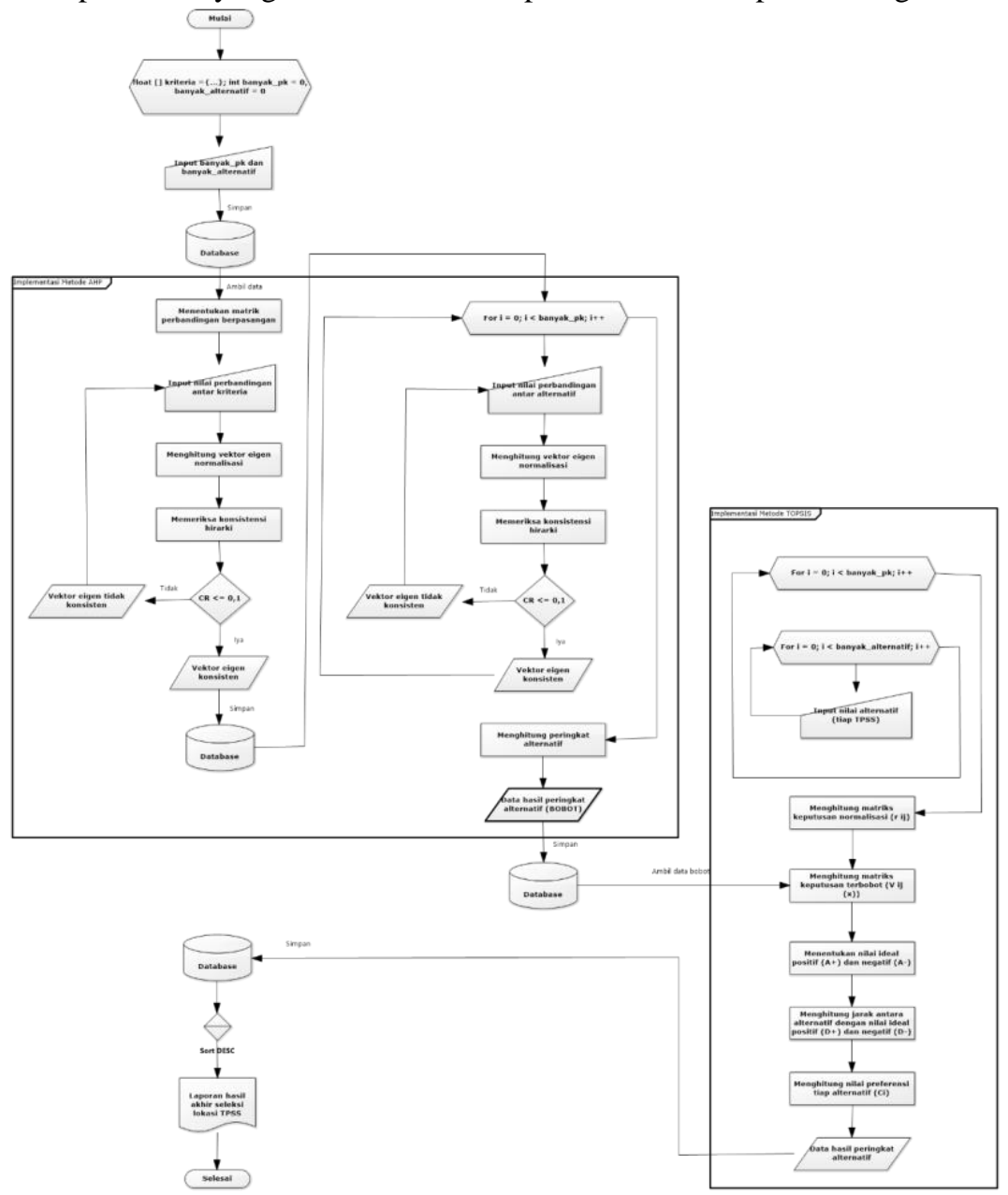

Gambar 6 Flowchart Hybrid AHP dan TOPSIS

1. Penerapan metode hybrid AHP dan TOPSIS pada sistem pendukung keputusan pemilihan lokasi Tempat Pembuangan Sampah Sementara (TPSS) terdiri dari beberapa langkah. Langkah pertama 
yaitu menentukan kriteria dan indikator kriteria yang akan dijadikan acuan dalam pemilihan. Selanjutnya menentukan setiap bobot kriteria untuk membandingkan tingkat kepentingan dari setiap kriteria. Dimana dalam menentukan sebuat bobot kriteria dalam penelitian ini menggunakan metode AHP yang menghasilkan jumlah nilai bobot sama dengan satu atau ternormalisasi. Setelah melakukan pembobotan kriteria, selanjutnya melakukan proses penilaian terhadap alternatif atau calon TPSS dengan menggunakan metode TOPSIS. Nilai preferensi alternatif (Ci) dijadikan acuan dalam menentukan peringkat calon TPSS baru. Semakin besar nilai yang didapat maka semakin baik pula kualitas dari calon TPSS tersebut. Nilai Ci terbesar pada penelitian ini sebesar 0,555 yaitu Transfer Depo Mastrip.

2. Proses pemilihan lokasi TPSS baru dengan menggunakan sistem pendukung keputusan lebih baik dan efisien dari pada menggunakan sistem manual. Dimana pada sistem manual penilaian pemilihan lokasi TPSS tidak memiliki penilaian yang baku, yang hanya mengandalkan persepsi pengambil keputusan dan juga membutuhkan waktu yang lumayan lama untuk memutuskan calon lokasi TPSS yang akan dipilih.

\section{Acknowledgements}

Ucapan terima kasih disampaikan peneliti kepada:

1. Fakultas Ilmu Komputer Universitas Jember.

2. Prof. Dr. Saiful Bukhori, ST., M.Kom., selaku Dosen Pembimbing Utama, dan Gayatri Dwi Santika, S.SI., M.Kom., selaku Dosen Pembimbing Anggota.

3. Bapak Adrian S. Sapnadi, SP., selaku Kepala Bidang Kebersihan di Dinas Lingkungan Hidup Kabupaten Jember.

\section{References}

[1] Bianchini, A. 2018. 3PL provider selection by AHP and TOPSIS methodology. Jurnal Benchmarking: An International Journal. 25(1): 235-252.

[2] Billah, E. 2019. Pengertian dan Tahap Metode SDLC Waterfall. https://medium.com/@ersandibillah03/sdlcwaterfall-

3a3c893be77b\#: :text=Model\%20Waterfall\%20adalah\%20suatu\%20proses, \%2C\%20pemodelan\%2C\%20impleme ntasi\%20dan\%20pengujian. [Diakses pada 28 November 2020].

[3] Chamid, A.A., dan A. C. Murtia. 2017. Kombinasi Metode AHP dan TOPSIS pada Sistem Pendukung Keputusan. Prosiding SNATIF ke-4. -: 115-119.

[4] Diana. 2018. Metode Dan Aplikasi Sistem Pendukung Keputusan. Palembang: Deepublish Publisher.

[5] Fachrial, A., Z. Arifin., dan D. M. Khairina. 2017. Sistem pendukung keputusann penentuan lokasi pembuangan akhir sampah kota samarinda metode simple additive weighting berbasis desktop. Prosiding Seminar Ilmu Komputer dan Teknologi Informasi. 2(1): 142-145.

[6] Hasibuan, Z.A. 2007. Metodologi Penelitian Pada Bidang Ilmu Komputer dan Teknologi Informasi, Konsep, Teknik dan Aplikasi. Jakarta: FIK-UI.

[7] Josuabrainly. 2015. Pengertian hybrid adalah. https://brainly.co.id/tugas/2673957. [Diakses pada 12 Januari 2021].

[8] Mattalatta, A. 2008. UU Nomor 18 Tahun 2008 Tentang Pengelolaan Sampah. Jakarta: Negara Republik Indonesia.

[9] Pambudi, R. A., A. B. Prasetijo., dan Y. E. Windarto. 2019. Implementasi topsis (techniquie for order preference by similarity) untuk penentuan tempat pembuangan akhir. Jurnal Informatika UPGRIS. 5(2): 163-168.

[10] Pratiwi, R.A., Statiswaty, dan LM. Tajidun. 2016. Sistem Penunjang Keputusan Penentuan Lokasi Terbaik Tempat Pembuangan Sampah Sementara Menggunakan Metode Brown Gibson. semanTIK. 2(2): 125-134.

[11] Saputra, A. 2017. Implementasi Metode Hybrid MCDM pada Sistem Pendukung Keputusan Pemilihan Pustakawan Berprestasi (Studi Kasus: UPT Perpustakaan Universitas Andalas). Prosiding Lokakarya Nasional Dokumentasi dan Informasi 2017. PDII LIPI: 271-285.

[12] Sari, D. R., A. P. Windarto., D. Hartama, dan Solikhun. 2018. Sistem pendukung keputusan untuk rekomendasi kelulusan sidang skripsi menggunakan metode AHP-TOPSIS. Jurnal Teknologi dan Sistem Komputer. 6(1): 1-6.

[13] Soedradjat, I. 1994. Pedoman Pemanfaatan Kawasan Sekitar TPA Sampah. Jakarta: Penataan Ruang Nasional.

[14] Sugiyani, Y. 2016. Sistem pengambilan keputusan penentuan lokasi tempat pembuangan akhir (tpa) sampah menggunakan metode simple addictive weighting (saw). Jurnal Sistem Informasi. 3(-): 1-7.

[15] Syafnidawaty. 2020. Multi Criteria Decision Making (MCDM). https://raharja.ac.id/2020/04/11/multi-criteriadecision-making-mcdm/. [Diakses pada 20 Januari 2021].

[16] Syafnidawaty. 2020. Kelebihan dan Kekurangan Metode AHP (Analytic Hierarchy Proses). https://raharja.ac.id/2020/04/01/kelebihan-dan-kekurangan-metode-ahp-analytic-hierarchy-process/. [Diakses pada 22 Januari 2021].

[17] Syafnidawaty. 2020. Kelebihan dan Kelemahan Metode TOPSIS. https://raharja.ac.id/2020/04/09/kelebihan-dankekurangan-metode-topsis/. [Diakses pada 22 Januari 2021].

[18] - . 2012. Buku Putih Sanitasi Kabupaten Jember. Jember: PPSP. 